and one at $900 \mathrm{MW}$ in 1982-83. But since then, Electricité de France has revised downwards its electricity demand projections for 1990 . The new government's target of six 1,300 MW reactors and one $900 \mathrm{MW}$ reactor is commensurate with the new projections.

More identifiably new are proposals for public and regional consultation over nuclear decisions, and the establishment of several new energy committees. But, in the end, power seems likely to rest firmly at the centre.

There will be an "observatoire de l'energie" at the Ministry of Industry, to act as an information bank; a "regional energy agency" under each Assemblée Regionale; and adversary, representative local information commissions set up on each power station, reprocessing or fuel assembly site.

The regional energy agencies will also be representative - consisting mostly of elected members, together with some union, public and interest group representation - and their first enormous task will be to prepare a full regional energy plan. These councils will consider local economic, demographic and geographical factors and devise a plan of action including a politics of information, research, development and financial support.

Other plans outlined are for the National Assembly to set up an of fice of technology assessment and for a permanent delegation for energy at the assembly, to consider matters of safety and security. The expert Conseil Supérieur de la Sûreté Nucléaire will be reinforced and its composition "modified".

On the remaining nuclear questions reprocessing and the fast breeder - the French government is allowing itself only a little more time. Construction to double the capacity of the existing plant at Cap de la Hague is due to begin next March; and in the interim a special scientific commission will investigate all questions concerning reprocessing (including the poor functioning of the present plant), and report to government and parliament. Superphénix, the commercial demonstration fast reactor at Isère, will be started up; but decisions on the commercial development of the fast breeder will be deferred to 1984-85.

Meanwhile, Quilès and his many erstwhile followers in the socialist party feel let down. Although none goes quite as far as M. Michel Rocard, leader of a socialist party faction and previously a contender for the presidency. "What's happening to the party is an historical scandal" a Paris paper reported him as saying last week. "Never in the international workers' movement including Lenin's time - has there been such an attempted internal putsch so cynical and so empty of principles." $\mathrm{M}$. Rocard, it seems, was not referring solely to energy policy.

\title{
Keyworth takes on health risks
}

\section{Washington}

In a small but potentially significant realignment of Washington responsibilities, the new director of the Office of Science and Technology Policy, Dr George (Jay) Keyworth, has agreed to be the chairman of a group which is being established to coordinate the scientific aspects of federal policy on safety, health and environmental regulation.

Under the Carter Administration, this coordination function was carried out by the Interagency Regulatory Liaison Group (IRLG). Chaired by the then administrator of the Environmental Protection Agency, Dr Doug Costle, IRLG provided a forum in which federal agencies could coordinate their efforts on common or overlapping problems. In 1979, for example, IRLG published a report on the scientific bases for identification of potential carcinogens and estimation of risks prepared by a working group with representatives of four regulatory agencies and headed by Dr Eula Bingham, then head of the Occupational Safety and Health Administration. This group agreed that any substance shown to cause cancer in laboratory animals should be treated as a potential human carcinogen.

\section{Conflicts of interest}

\section{Tighter controls}

\section{Washington}

Leading research universities across the United States are suddenly having to tighten up the rules which cover potential conflicts of interest between the academic and commercial activities of individual research workers. Their efforts stem from the growing need to order the complex web of relationships caused by the rapidly increasing ties between university and corporate research efforts.

In most cases, the demand for tighter conflict-of-interest rules has come from within the universities. Two weeks ago, for example, the faculty council of Harvard University agreed to recommend to the full faculty a new set of procedures which would establish a Faculty Committee on Conflicts of Interest. If adopted, the procedures would, for the first time, require certain faculty members to disclose details of their outside commitments, as well as formally restricting such commitments to 20 per cent of their time.

There has also been pressure for stricter control from outside. In California a federally-funded public interest group, California Rural Legal Assistance (CRLA), has demanded that research workers at the University of California should no longer be exempt from a law requiring all state officials to disclose their economic interests. Last Monday the
The new heads of the regulatory agencies, appointed by Mr Reagan, have adopted a substantially different approach to their mandate,emphasizing ways of cutting back on health and environmental regulation rather than adding to it. They have decided to let IRLG disappear, but they have agreed to support a new group, provisionally entitled the Interagency Science/Health Coordination Group, chaired by the President's science adviser, Dr Keyworth.

Dennis Prager, OSTP's assistant director for life sciences and institutional relations, explained that the working group set up under Vice-President George Bush to look at ways of reducing the burden of regulation on private industry had recognized the need for both a scientific contribution their discussion and for continued interagency coordination, and had felt that "the best way to do that was to upgrade the interagency council and give it more clout by being chaired by Jay Keyworth." $\mathrm{Mr}$ Prager said that the group would be trying to strengthen the scientific basis for regulatory decisions and develop methods of risk assessment.

David Dickson

state's Fair Political Practices Commission agreed that CRLA's staff should look into alternative regulations for university employees.

The debate on how a scientist should strike a reasonable balance between his or her teaching and research commitments to the university and those as consultants for outside companies is not new to US academic life. However, it has been given a new twist by three particular elements.

Two spring directly from recent changes in federal policy. The first is a set of legislative measures, such as tax incentives and patent law reform, designed explicitly to tighten the links between the academic and the corporate world. The second is the growing squeeze on federal research funds, inevitably leading university scientists to seek corporate sponsorship with greater zeal.

At Harvard the need for new guidelines was highlighted last year when the university's president, Dr Derek Bok, made a proposal which he subsequently retracted - that the university should have an equity share in Genetics Institute, a company being established on venture capital funding by Dr Mark Ptashne, professor of molecular biology.

Harvard's new rules would require that faculty members consult with a new committee, chaired by the dean of the faculty of arts and sciences, about any activities that "seemed to present an unacceptable conflict of interest or commitment". These include cases where a 